\title{
GAMBARAN PRAKTEK IBADAH SHOLAT PASIEN YANG DIRAWAT DIRUMAH SAKIT X
}

\author{
Murtiningsih ${ }^{1)}$, Nedra Wati Zaly ${ }^{2)}$ \\ 1 Prodi Ners, STIKes Jayakarta \\ email: murtiningsihkadun@gmail.com \\ 2 Prodi Sarjana Keperawatan, STIKes Jayakarta \\ email: nedrawati12@gmail.com
}

\begin{abstract}
Prayer is an obligation for every Muslim from baligh to the end of life. Patients who are admitted to the Hospital there are Rukhshah (ease of doing worship). If the patient is unable to stand up, then prayer can be done by sitting, lying down or by gesturing. This study aims to get an overview of the prayer practice of patients being admitted to the hospital and the reasons for the patients not praying while being admitted to the hospital. The sample of this study was 65 patients admitted to the Hospital X that were collected by Jayakarta STIKes Students when conducting spiritual studies patients to do nursing care when practicing nurses basic nursing profession in the Academic Year 2019/2020. The questionnaire includes a spiritual assessment contained in the portfolio. The research method is cross sectional study with descriptive studies. The results showed the majority of patients $(41.5 \%, N=65)$ during their admitted to the hospital had never prayed. The reason for patients not praying while being admitted to the Hospital the majority $(23.1 \%)$ is because they do not know how to pray, before being sick they rarely pray (18.5\%), some (9.2\%) argue that if there is no need to pray, there is no prayer equipment (4.6) \%). Recommendations for further research are research on nurses' knowledge about prayer for patients admitted to the hospitals. Furthermore, nurses need to be given training on the practice of prayer and rukhshah to worship for patients admitted to the hospitals.
\end{abstract}

Keywords: Prayer practice, patients, admitted to the Hospital.

\section{PENDAHULUAN}

Sholat merupakan kewajiban setiap umat Muslim sejak mulai baligh hingga akhir hayat. Pasien yang dirawat di Rumah Sakit ada Rukhshah (kemudahan melakukan ibadah karena keuzuran). Jika pasien tidak mampu berdiri, maka sholat dapat dilakukan dengan duduk, berbaring ataupun dengan isyarat. Sholat merupakan hal yang penting bagi umat Muslim. Penelitian ini bertujuan untuk mendapatkan gambaran praktek ibadah sholat pasien yang dirawat di Rumah Sakit dan alasan pasien jika tidak melakukan sholat ketika dirawat di Rumah sakit.

\section{A. Ibadah Sholat}

Shalat wajib hukumnya atas setiap muslim yang berakal dan sudah mencapai akhir baligh, baik itu laki-laki maupun perempuan, kaya atau miskin, orang yang berdomisili atau dalam keadaan musafir, dalam keadaan sehat atau sakit, dan kewajiban shalat yang lima waktu sehari semalam (Abdullah, 2017).

Kewajiban shalat tidak akan pernah lepas dari seorang Muslim. Shalat tidak dapat gugur hanya karena alasan bepergian atau sakit (Ath-Thayyar, 2007)

Kewajiban shalat yang lima waktu sehari semalam tidak boleh ditinggalkan walaupun dia dalam keadaan sakit, selama akalnya masih sehat sampai kematian datang menjemputnya, sebagaimana Allah firman dalam Surat An_Nisaa: 103

"Sesungguhnya Shalat itu adalah kewajiban yang ditentukanwaktunya atas orang-orang yang beriman" 
B. Rukhsah ibadah sholat

Prinsip rukhsah dalam ibadah bertujuan merespon berbagai realitas kondusif yang terjadi dalam kehidupan manusia. Prinsip pendirian shalat bagi orang sakit berbeda dengan orang yang sehat. Orang yang sakit diperbolehkan untuk mendirikan shalat sebatas kemampuan yang dia miliki (Ath-Thayyar, 2007).

Ajaran Islam dibangun berlandasan kemudahan dan keringanan, maka dari itulah Allah memberikan keringanan bagi orangorang yang mempunyai udzur di dalam peribadatan sesuai dengan udzurnya, sehingga mereka dapat beribadah kepada-Nya tanpa kesulitan.

Allah Ta'ala berfirman:

"Dan Dia sekali-kali tidak menjadikan untuk kamu dalam agama suatu kesempitan" (AlHajj: 78)

"Allah menghendaki kemudahan bagimu dan Dia tidak menghendaki kesulitan bagimu” (AlBaqarah: 185).

Maka bertaqwalah kamu kepada Allah menurut kesanggupanmu dan dengarlah serta taatlah" (At-Taghabun:16).

\section{Thaharah}

Sesungguhnya Allah سبحانه و تعالي telah menetapkan kewajiban bersuci untuk setiap shalat, karena sesungguhnya wudhu menghilangkan hadats dan najis, baik pada tubuh, pakaian atau tempat shalat, keduanya merupakan bagian dari syarat sah shalat. Apabila seorang muslim hendak melakukan shalat, maka wajib berwudhu (bersuci) dari hadats kecil, atau mandi terlebih dahulu jika berhadats besar. Dan sebelum berwudhu, harus beristinja (bersuci) dengan air atau beristijmar dengan batu jika buang air kecil atau buang air besar, agar kesucian dan kebersihan menjadi sempurna (Azis, 2009).

Pasien yang sakit, apabila tidak bisa bersuci dengan menggunakan air, seperti berwudhu dari hadits kecil atau mandi dari hadats besar, karena lemah atau khawatir akan bertambah parah atau kesembuhannya akan tertunda, maka orang tersebut boleh bertayammum, yaitu menepukkan kedua telapak tangan ke tanah yang suci satu kali, lalu menyapu mukanya dengan telapak jari-jari dan kedua tangan dengan telapak tangannya; karena Allah berfirman:

"Hai orang-orang yang beriman, apabila kamu hendak mengerjakan sholat, maka basuhlah mukamu dan tanganmu sampai dengan siku, dan usaplah kepalamu dan basuh kakimu sampai dengan kedua mata kaki. Dan jika kamu junub maka mandilah, dan jika kamu sakit atau dalam perjalanan atau kembali dari tempat buang air (kakus) atau menyentuh perempuan, lalu kalian tidak memperoleh air, maka bertayamumlah dengan tanah yang baik (bersih); sapulah mukamu dan tanganmu dengan tanah itu. (Al-Ma`idah: 6).

D. Tata cara Sholat bagi orang yang sakit

Para ulama sepakat bahwa barangsiapa yang tidak mampu melakukan shalat dengan berdiri hendaknya shalat sambil duduk, dan jika tidak mampu dengan duduk, maka shalat sambil berbaring dengan posisi tubuh miring dan menghadapkan muka ke kiblat. Disunnatkan miring dengan posisi tubuh miring di atas tubuh bagian kanan. Dan jika tidak mampu melaksanakan shalat dengan berbaring miring, maka orang tersebut boleh shalat dengan berbaring telentang, sebagaimana sabda Nabi صلي الله عليه وسلم kepada 'Imran bin Hushain:

"Shalatlah kamu sambil berdiri, dan jika kamu tidak mampu, maka sambil duduk, dan jika tidak mampu, maka dengan berbaring” (HR. Bukhari).

Berikut ini beberapa tata cara ibadah sholat pada orang yang sakit (Ath-Thayyar, 2007):

1. Orang yang sakit harus bersuci dengan air terlebih dahulu untuk menghilangkan hadas besar dan kecil. Apabila ada halangan dalam menggunakan air, boleh bertayammum.

2. Membersihkan pakaian dan badan dari najis. Apabila tidak mampu, orang sakit boleh shalat dengan keadaan yang ada. Shalatnya tetap sah dan tidak wajib mengulang.

3. Shalat di atas tempat yang suci. Apabila tidak memungkinkan, boleh shalat dimana saja. Shalatnya tetap sah dan tidak wajib mengulang.

4. Orang sakit yang mampu berdiri, akan tetapi tidak mampu ruku' atau sujud, maka harus shalat sambal berdiri lalu ruku' dengan isyarat (menundukkan kepala), kemudian 
duduk dan sujud dengan berisyarat; karena firman Allah

"...Dan berdirilah karena Allah (dalam shalatmu) dengan khusyu'” (Al-Baqarah: 238).

5. Orang sakit yang tidak mampu duduk, maka boleh sholat dalam keadaan berbaring menghadap kiblat. Ruku' dan sujudnya dengan gerakan isyarat. Isyarat sujud diupayakan lebih rendah daripada ruku'.

6. Orang sakit yang tidak mampu shalat berbaring, sebagian ulama berpendapat boleh shalat bersandar pada kepala dan kaki ke arah kiblat, disebut posisi telentang. Ruku' dan sujudnya dengan gerakan isyarat kedipan mata. Sedikit memejamkan mata untuk isyarat ruku', dan memejamkan lebih lama untuk isyarat sujud.

7. Orang sakit yang tidak mampu melakukan isyarat dengan kepala ataupun mata, maka dengan niat dan bacaan saja, dan kewajiban shalat tetap tidak gugur darinya dalam keadaan bagaimanapun selagi ia masih sadar (berakal).

8. Dan apabila ditengah-tengah shalat, orang yang sakit mampu melakukan apa yang tidak mampu dilakukan sebelumnya, seperti berdiri, ruku', sujud atau berisyarat dengan kepala, maka pasien harus melakukan apa yang mampu, dan melanjutkan shalat tersebut.

9. Apabila pasien tertidur atau lupa melakukan shalat atau karena lainnya, pasien wajib menunaikannya di saat ia bangun atau di saat ia ingat, dan tidak boleh menundanya kepada waktu berikutnya. Sebagaimana sabda Rasulullah صلي الله عليه وسلم :

"Barangsiapa tertidur atau lupa melakukan shalat, maka hendaknya ia menunaikannya pada saat ia ingat, tidak ada tebusan lain baginya kecuali hanya itu". Lalu beliau membaca firman Allah: "dan dirikanlah shalat untuk mengingatKu”. (Thaha: 14).

10. Orang yang sakit tidak diperbolehkan untuk menunda shalat dari waktu yang telah ditetapkan selama hal itu tidak memberatkan dirinya. Namun, apabila memberatkannya untuk mendirikan shalat pada waktu yang telah ditetapkan, orang yang sakit boleh menjamak shalat baik jamak taqdim maupun takhir. Adapun shalat Subuh, (tetap dilakukan seperti biasa) tidak bisa dijama' dengan shalat sebelum atau sesudahnya.

ada tebusan lain baginya kecuali hanya itu”. Lalu beliau membaca firman Allah: "dan dirikanlah shalat untuk mengingatKu”. (Thaha: 14).

E. Hukum meninggalkan sholat

Menurut Muhammad, S (2009) menyatakan bahwa tidak ada alasan bagi seseorang di dalam Islam untuk meninggalkan shalat, barang siapa meninggalkannya dengan sengaja maka dia telah kafir.

Hal ini sesuai dengan firman Allah SWT:

"Dengan kembali bertaubat kepada-Nya dan bertakwalah kepadaNya serta dirikanlah shalat dan janganlah kamu termasuk orang-Orang yang mempersekutukan Allah." (Ar-Ruum: 31). Nabi sallallahu alaihi wa sallam bersabda:

"Janganlah engkau meninggalkan shalat yang diwajibkan dengan secara sengaja, barang siapa meninggalkannya dengan secara sengaja maka telah terlepas darinya tanggungan (Allah)." (HR. Ibnu Maajah).

\section{METODE}

Metode penelitian ini adalah studi deskriptif yang bertujuan mendapatkan gambaran tentang praktek ibadah sholat pasien yang dirawat di Rumah Sakit dan alasan jika tidak melakukan sholat ketika dirawat di Rumah Sakit . Sampel dalam penelitian ini menggunakan purposive sampling sebanyak 65 pasien Muslim yang dirawat di Rumah Sakit. Alat pengumpulan data menggunakan kuesioner pengkajian spiritual yang terdapat dalam portofolio mahasiswa saat praktek ners keperawatan dasar profesi. Analisa data menggunakan distribusi frekuensi. 


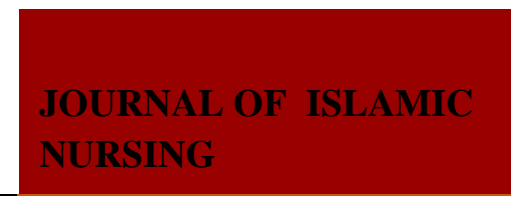

\section{HASIL PENELITIAN}

Tabel 1. Distribusi frekuensi Gambaran Praktek Ibadah Sholat Pasien di Rumah Sakit X, N=65

\begin{tabular}{lcc}
\hline & \multicolumn{2}{c}{ Praktek Ibadah Sholat Pasien di RS } \\
\cline { 2 - 3 } & Frekuensi & Prosentase \\
\hline Tidak pernah & 27 & $41.5 \%$ \\
\hline Kadang-kadang & 10 & $15.4 \%$ \\
\hline Sering & 14 & $21.5 \%$ \\
\hline Selalu & 14 & $21.5 \%$ \\
\hline TOTAL & 65 & $100 \%$ \\
\hline
\end{tabular}

Berdasarkan tabel 1 didapatkan mayoritas pasien $(41.5 \%)$ selama dirawat di Rumah Sakit

tidak pernah melakukan sholat.

Tabel 2. Distribusi frekuensi alasan tidak sholat selama dirawat di Rumah Sakit $X, N=65$

\begin{tabular}{lcc}
\hline \multicolumn{3}{l}{ Alasan Pasien Tidak melaksanakan Ibadah Sholat di RS } \\
\hline & Frekuensi & Prosentase \\
\hline Tidak menjawab & 27 & $41.5 \%$ \\
\hline $\begin{array}{l}\text { Sebelum sakit jarang } \\
\text { sholat }\end{array}$ & 12 & $18.5 \%$ \\
\hline Tidak tahu cara sholat & 15 & $23.1 \%$ \\
\hline $\begin{array}{l}\text { Tidak ada perlengkapan } \\
\text { sholat }\end{array}$ & 3 & $4.6 \%$ \\
\hline $\begin{array}{l}\text { Kalau sakit tidak perlu } \\
\text { sholat }\end{array}$ & 6 & $9.2 \%$ \\
\hline Lain-lain & 2 & $3.1 \%$ \\
\hline TOTAL & 65 & $100 \%$ \\
\hline
\end{tabular}

Tabel 2 menunjukkan alasan pasien tidak melakukan ibadah sholat ketika dirawat di Rumah sakit mayoritas (23.1\%) karena tidak tahu cara sholat, sebelum sakit jarang sholat (18.5\%), sebagian $(9.2 \%)$ berpendapat kalau sakit tidak perlu sholat, serta tidak ada perlengkapan sholat $(4.6 \%)$

\section{PEMBAHASAN}

Berdasarkan tabel 1 didapatkan mayoritas pasien $(41.5 \%)$ selama dirawat di Rumah Sakit tidak pernah melakukan sholat. Pasien yang melakukan sholat selama dirawat di Rumah Sakit terbagi dalam 3 kategori yaitu kadang-kadang $(15,4 \%)$, Sering $(21,5 \%)$ dan selalu sholat $(21,5 \%)$.

Berdasarkan studi fenomenologi Pengalaman Ibadah Pasien Islam yang di Rawat dengan Pendekatan Spiritual Islam di Rumah
Sakit Aisyiah Bojonegoro dan Rumah Sakit Haji Surabaya didapatkan tidak semua pasien melaksanakan ibadah sesuai yang diperintahkan agama yaitu sholat wajib lima waktu. Hal ini disebabkan kelemahan kondisi fisik pasien dan pasien dalam keadaan tidak suci. Hal tersebut juga dipengaruhi oleh kurang dilaksanakannya asuhan keperawatan spiritual oleh perawat (Abu Bakar, 2013)

Hasil penelitian ini sejalan dengan penelitian sebelumnya yaitu penelitian tentang Knowledge, Attitude, and Practice sholat Pasien yang dirawat di Hospital Langkawi Malaysia menunjukkan bahwa 78,9\% tidak melakukan sholat ketika dirawat di Rumah Sakit (Aris, Jaafar, \& Umar, 2017).

Pasien yang tidak melakukan sholat dapat dipengaruhi oleh pengetahuan, sikap dan keterampilan dari pasien dan pemberi pelayanan 
kesehatan tentang rukhshah ibadah sholat. Dalam penelitian (Jaafar \& Aris, 2016) tentang Knowledge, Attitude, and Practice religious dari pemberi pelayanan kesehatan didapatkan data $73(60,3 \%)$ responden mempunyai pengetahuan yang baik, $62(51.2 \%)$ menunjukkan sikap yang baik dan 73 (60.3\%) memiliki ketrampilan yang baik tentang rukhshah.

Pengetahuan perawat tentang pemenuhan kebutuhan spiritual dapat ditingkatkan melalui pelatihan. Penelitian quasi eksperimen telah dilakukan dengan memberikan pelatihan kepada perawat tentang pemenuhan kebutuhan spiritual. Hasil penelitian menunjukkan terdapat peningkatan nilai rata-rata pemenuhan kebutuhan spiritual sebelum intervensi 55, 23 menjadi 57,18 setelah intervensi (Wardah, Rizka Febtrina, 2017)

Tabel 2 menunjukkan alasan pasien tidak melakukan ibadah sholat ketika dirawat di Rumah sakit mayoritas (23.1\%) karena tidak tahu cara sholat, sebelum sakit jarang sholat (18.5\%), sebagian $(9.2 \%)$ berpendapat kalau sakit tidak perlu sholat, serta tidak ada perlengkapan sholat (4.6\%).

Sebagian responden berpendapat kalua sakit tidak perlu sholat. Berdasarkan hasil penelitian ini berarti sebagian pasien yang dirawat di Rumah sakit belum memahami bahwa orang yang sakit tetap wajib menjalankan shalat 5 waktu sesuai dengan kemampuannya.

Shalat wajib hukumnya atas setiap muslim yang berakal dan sudah mencapai akhir baligh, baik itu laki-laki maupun perempuan, kaya atau miskin, orang yang berdomisili atau dalam keadaan musafir, dalam keadaan sehat atau sakit, dan kewajiban shalat yang lima waktu sehari semalam (Abdullah, 2017).

Kewajiban shalat tidak akan pernah lepas dari seorang Muslim. Shalat tidak dapat gugur hanya karena alasan bepergian atau sakit (AthThayyar, 2007).

Kewajiban shalat yang lima waktu sehari semalam tidak boleh ditinggalkan walaupun dia dalam keadaan sakit, selama akalnya masih sehat sampai kematian datang menjemputnya, sebagaimana Allah firman dalam Surat
An_Nisaa: 103: "Sesungguhnya Sha/at itu adalah kewajiban yang ditentukanwaktunya atas orang-orang yang beriman"

Shalat tetap wajib dilaksanakan dalam keadaan sakit, kecuali pasien yang tingkat kesadarannya koma tidak wajib melakukan shalat. Shalat pada orang yang sakit ada rukhsah (kemudahan) pada saat pelaksanaannya.

Prinsip rukhsah dalam ibadah bertujuan merespon berbagai realitas kondusif yang terjadi dalam kehidupan manusia. Prinsip pendirian shalat bagi orang sakit berbeda dengan orang yang sehat. Orang yang sakit diperbolehkan untuk mendirikan shalat sebatas kemampuan yang dia miliki (Ath-Thayyar, 2007).

Berdasarkan penelitian (Aris et al., 2017) tentang Knowledge, Attitude, and Practice sholat Pasien yang dirawat di Hospital Langkawi Malaysia menunjukkan bahwa pasien berpendapat bahwa tidak ada orang yang membimbing untuk sholat $(48.2 \%, \mathrm{n}=80)$ dan membantu mengambil wudhu $(47.6 \%, \mathrm{n}=79)$.

Pelaksanaan ibadah sholat bagi pasien dipengaruhi oleh kondisi pasien maupun peran perawat dalam membantu pasien untuk melaksanakan shalat. Penelitian yang telah dilakukan (Azizah, 2019) didapatkan kemampuan pasien untuk wudhu dan shalat $75 \%$ dan tidak melaksanakan 25\%. Perawat mempunyai peranan dalam membantu pasien untuk melakukan sholat. Hasil penelitian menunjukkan $82,4 \%$ perawat mengingatkan waktu sholat dan $12,5 \%$ perawat tidak mengingatkan waktu shalat.

Dengan demikian peran perawat menjadi penting dalam membantu pasien melaksanakan ibadah shalat. Peran perawat tersebut dapat dilaksanakan jika perawat mempunyai pengetahuan dalam pemenuhan kebutuhan spiritual pasien.

\section{KESIMPULAN}

Berdasarkan hasil penelitian didapatkan sebagian besar $(41.5 \%)$ pasien yang dirawat di Rumah Sakit tidak melakukan ibadah Sholat. Alasan pasien tidak melakukan sholat karena sholat, kalau sakit tidak perlu sholat, tidak ada perlengkapan sholat. 
Rekomendasi hasil penelitian yaitu dapat dilakukan penelitian lanjutan tentang pengetahuan perawat tentang ibadah sholat bagi pasien yang dirawat di Rumah Sakit. Selanjutnya perawat perlu diberikan pelatihan tentang praktek ibadah sholat dan rukhshah (kemudahan) melakukan ibadah bagi pasien yang dirawat di Rumah Sakit. Pelatihan tecersebut untuk meningkatkan pengetahuan dan ketrampilan dalam membantu ibadah sholat pasien ketika dirawat untuk memenuhi kebutuhan spiritual pasien. Sehingga pasien mendapatkan asuhan keperawatan tidak hanya fisiknya saja tapi secara holistic meliputi bio, psiko, sosio, spiritual.

\section{REFERENSI}

Alqur'an Terjemahan.

Ath-Thayyar, Abdullah, Prof, DR. (2007). Ensiklopedia shalat. Penerjemah, AM. Halim, Jakarta: Maghfirah pustaka

Azis, S.A (2009). Hukum bersuci dan sholat bagi orang sakit. Ebook dari www.ibnumajjah.wordpress.com

Abdullah. (2017). Sholat (definisi, anjuran dan ancaman). Penerjemah. Syafiq Fauzi Bawazier. Ebook dari www.ibnumajjah.wordpress.com

Abu Bakar, N. D. K. (2013). Studi Fenomenologi Pengalaman Ibadah Pasien Islam yang di Rawat dengan Pendekatan Spiritual Islam di Rumah Sakit Aisyiah Bojonegoro dan Rumah Sakit Haji Surabaya. Critical,Medical, and Surgical Nursing Journal, 1(2), 115-118. Retrieved from https://ejournal.unair.ac.id/CMSNJ/article/view/12173/ 7059

Aris, S., Jaafar, H., \& Umar, N. S. (2017). KNOWLEDGE , ATTITUDE AND PRACTICE OF PERFORMING PRAYERS ( SALAT ) AMONG MUSLIM PATIENTS IN HOSPITAL LANGKAWI, KEDAH : ROLES OF MUSLIM HEALTHCARE. (May). https://doi.org/10.1166/asl.2017.8975

Azizah, N. dan P. M. (2019). Pelaksanaan Wudhu Tayamum D an Sholat Pasien Di Rumah Sakit. Jurnal Ilmu Keperawatan Dan Kebidanan, 10(2), 303-306.
Jaafar, H., \& Aris, S. (2016). Knowledge, Attitude and Practice towards Religious Obligations among Healthcare Workers in Hospital. (April 2019).

Wardah, Rizka Febtrina, E. D. (2017). PENGARUH PENGETAHUAN PERAWAT TERHADAP PEMENUHAN PERAWATAN SPIRITUAL PASIEN DI RUANG INTENSIF. Jurnal Endurance, 2(October), 436-443.

Muhammad, S. (2009). Hukum orang yang meninggalkan shalat. Terjemahan Harun, Y. Ebook dari www.ibnumajjah.wordpress 